\title{
The Practice of Open Innovation by SMEs in the Food Industry
}

\author{
S. Hijrat Sadat \\ Hijrat.sadat2010@gmail.com | Independent researcher, Belgium \\ Sayed Nasrat \\ Sayed.nasrat2@gmail.com | Maastricht Graduate School of Governance /United Nations \\ University-MERIT, Maastricht University, 6211 AX Maastricht, the Netherlands
}

\begin{abstract}
This paper examines the practice of open innovation by Small and Medium-sized Enterprises (SMEs) in the food industry. We adopted a multiple case study approach and conducted in-depth semistructured interviews with four food SMEs in the Flanders region of Belgium. The results of the analysis show that food SMEs practice open innovation mostly through inbound open innovation activities rather than outbound, mainly due to lack of sufficient resources. Food SMEs typically lack sufficient financial capital, technology, and human capital. Within inbound open innovation activities, collaboration with organizations is found to be a key element for food SMEs' internal development and innovation of new products.
\end{abstract}

Keywords. Open Innovation Practice; Food industry; SMEs; Inbound; Outbound; Collaboration.

Cite paper as: Sadat, S. H., Nasrat, S., (2020). The Practice of Open Innovation by SMEs in the Food Industry, Journal of Innovation Management, www.open-jim.org, 8(2), 26-46. 


\section{Introduction}

Small and Medium-sized Enterprises (SMEs) play a vital role in national economies by generating employment opportunities and are important contributors to value creation as well as innovation (Organization for Economic Co-operation and Development [OECD], 2017). To achieve and sustain competitive advantage in the market, many SMEs depend on their ability to be innovative (Parida, Westerberg, \& Frishammar, 2012). However, innovation as a tool for development is usually challenging for SMEs compared to large firms. For instance, SMEs are subject to limited resources and innovation capabilities that larger firms acquire more easily (Lee, Park, Yoon, \& Park, 2010). Therefore, these limitations may hamper their ability to compete and survive in the current competitive business environment. Studies related to innovation proposed opening the innovation process in order to overcome these limitations for SMEs (Parida et al., 2012). This means a shift from a closed innovation model to an open innovation model (Chesbrough, 2003; Gassmann, 2006).

Adequate studies on the adoption or practice of open innovation by SMEs are lacking in the extant literature because they have predominantly focused on large or multinational firms (e.g., Parida et al., 2012; Hutter, Hautz, Repke, \& Matzler, 2013; Bogers et al., 2017). Acknowledging this gap, Bigliardi \& Galati (2013) suggested that much attention should be given on the practice of open innovation in the food industry by academia. Additionally, after reviewing the existing literature, we found that open innovation by SMEs in the food industry has still received less attention. Moreover, it is important to focus on the food industry because SMEs in this industry experience more complex challenges such as high regulations and high local and international competition (Saguy \& Sirotinskaya, 2016). This is due to various reasons, such as the nature of food production, involving several actors and the various, and inconsistent requirements that must be met by the food firms (see Section 2). Therefore, this study attempts to provide further understanding of how food SMEs practice open innovation.

More specifically, this study focuses on food SMEs in the Flanders region of Belgium. This is due to several reasons. In the first instance, in terms of geographical distribution, more than half of SMEs in Belgium are located in the Flanders region (de Best, 2019). Furthermore, in Belgium, as in the rest of the EU member countries, SMEs are the backbone of the economy. For example, in 2013 SMEs constituted 99.9\% of all firms in Belgium (OECD, 2016). This is due to the fact that in terms of firm size, all firms with 1-249 employees are considered an SME (OECD, 2015). According to the Federation of the Belgium Food Industry (FEVIA) ${ }^{1}$, the Belgian food industry is an actual SME sector because the vast majority (96\%) of employers have less than 100 employees (FEVIA, 2017-2018). With the main focus on food SMEs in the Flanders region of Belgium, this study tries to answer the question of: How do food SMEs practice open innovation?

$1 \quad$ FEVIA is the federation of food industry in Belgium and represents 700 innovative food and/or beverage companies (for more details visit https://www.fevia.be/nl). 


\section{Literature Review}

\subsection{Open Innovation}

The concept of open innovation was first introduced by Henry Chesbrough in 2003 (Chesbrough, 2003). This concept is defined as, "the use of purposive inflows and outflows of knowledge to accelerate internal innovation, and expand the markets for external use of innovation, respectively" (Chesbrough, Vanhaverbeke, \& West, 2006, p. 1). Since its introduction, this concept has gained importance among academics and practitioners (Usman, Roijakkers, Vanhaverbeke, \& Frattini, 2018). Although Chesbrough (2003) described the differences between open and closed innovation models (see Appendix A), the concept of open innovation has been criticized. For example, a study by Trott and Hartmann (2009) indicates no real paradigm shift from closed to open innovation approaches. This is because they argued that firms have always practiced open innovation and no firms at any time have followed closed innovation in their innovation procedure. In addition, Duarte and Sarkar (2011) argued that the concept of open innovation is not entirely new, because collaboration among firms or organizations has been taking place for many years. In 2014, Chesbrough and Bogers responded to the critics on the concept and development of open innovation in the literature (Chesbrough \& Bogers, 2014). The concept of open innovation covers more research areas than how it was studied in the past (Muller, Hutchins, \& Pinto 2012). For example, the application of open innovation, at first mainly started in the high-tech sector. However, later it spread into different sectors, including food, machinery, and architecture (Gassmann, Enkel, \& Chesbrough, 2010).

\subsection{Open Innovation and SMEs}

SMEs face several challenges with innovation in contrast to the large enterprises or firms. These challenges include lack of resources, smallness, commodity pressure (Dahlander \& Gann, 2010; Rahman \& Ramos, 2010), and inability to perform all their Research \& Development (R\&D) activities internally (Gassmann, 2006). Van de Vrande, Jong, Vanhaverbeke, \& De Rochemont (2009) pointed out that these challenges can be resolved, if or when the SMEs practice open innovation effectively. However, the success of practicing open innovation effectively depends on various factors. Durst and Ståhle (2013) identified success factors of open innovation and grouped them into nine dimensions: relational issues, people, governance, facilitators, resources, strategy and leadership, culture and open innovation process. Among them, the three key success factors are relational issues (e.g., trust and partner compatibility), governance (e.g., coordination and control, mechanism and structures) and people, such as individuals' education, skills, capacities, commitment, among others (Durst \& Ståhle, 2013). In terms of processes or activities, open innovation is commonly categorized into two types: inbound and outbound open innovation (e.g., Huizingh, 2011; Parida et al., 2012). The inbound open innovation cited as the "internal use of external knowledge, while outbound open innovation refers to external exploitation of internal knowledge" (Huizingh, 2011, p.4). Dahlander and Gann (2010) further classified inbound and outbound open innovation activities into sub-categories, which are illustrated in Table 1 below. 
Table 1. Classification of open innovation

\begin{tabular}{lll}
\hline Perspective & Inbound open innovation & Outbound open innovation \\
\hline Controlled/formal & $\begin{array}{l}\text { Acquiring } \\
\text { How do firms acquire or in-license } \\
\text { input to the innovation process } \\
\text { through the marketplace? }\end{array}$ & $\begin{array}{l}\text { Selling } \\
\text { How do firms commercialize their } \\
\text { internally-developed technologies } \\
\text { or inventions via out-licensing or } \\
\text { selling? }\end{array}$ \\
& & $\begin{array}{l}\text { Revealing } \\
\text { Libre/informal }\end{array}$ \\
& $\begin{array}{l}\text { Sourcing } \\
\text { How do firms use external } \\
\text { sources for internal innovation or } \\
\text { development? }\end{array}$ & $\begin{array}{l}\text { Hevealed to the external resources } \\
\text { environment by a firm without } \\
\text { immediate financial reward? }\end{array}$ \\
\hline
\end{tabular}

Source: Adapted from Dahlander \& Gann, 2010; Virlee et al., 2015

The types of open innovation have their own advantages and disadvantages, which can be seen from the above table. For instance, the benefits of outbound innovation of a firm or SME can be both strategic and monetary (Lichtenthaler \& Ernst, 2007). However, it can also be risky due to the possibility of revealing internal resources or knowledge, which in turn can better position or strengthen the competitors of the firm in the market (Dahlander \& Gann, 2010). A firm can acquire external resources or knowledge through inbound open innovation activities (Chesbrough \& Crowther, 2006). Nonetheless, to do so, a firm requires money, time, and the ability to take advantage effectively from the acquired resources or knowledge to the innovation process (Bapuji, Loree, \& Crossan, 2011). The inbound (acquiring and sourcing) and outbound (selling and revealing) open innovation can be practiced through different sub-activities. A firm can carry out the task of acquiring knowledge through formal networking, cooperation or collaboration, in-licensing, and outsourcing R\&D. On the other hand, the task of sourcing the knowledge by a firm can be carried out through activities such as customer participation and informal networking. Activities of selling the inventions and technology include venturing and out-licensing to other enterprises (Virlee et al., 2015). Unlike selling, a firm can carry out the revealing task through any activities without receiving financial rewards in the short term (Dahlander \& Gann, 2010).

The above Table indicates that resources are crucial for SMEs to carry out their inbound and outbound open innovation activities. Firms contain resources such as: assets, organizational processes, capabilities, knowledge, attribute and information, so on (Daft, 1983 as cited in Barney, 1991). According to Ray, Barney, \& Muhanna (2004), resources are used by firms "to develop and implement their strategies" (p. 24). The management of a firm's strategic resources is central in order to achieve sustained competitive advantage and performance, which is called Resource Based Theory (e.g., Barney, 1991; Barney, Ketchen, \& Wright, 2011). In order to gain sustained competitive advantages, a firm resource must be: valuable, rare, inimitable, and non-substitutable (Barney, 1991). Open innovation is one of the strategies embraced by firms to survive and have sustainable competitive advantage in the fast-changing business environment (Lee \& Yoo, 2019). Taking a dynamic capability perspective, Lee \& Yoo (2019) identified that the success of open innovation can be accomplished by merging three aspects. These are: (1) 
sensing capability (firms collecting information on changes in the market to promptly respond to a competitive environment); (2) seizing capability (firms acquiring knowledge to benefit product innovation and its success); and (3) transforming capability (firms rearranging available resources to accomplish the cited activities successfully).

\subsection{Open Innovation and SMEs in the Food Industry}

Traditionally, the food processing industry develops relatively slow with a much lower level of R\&D investment compared to industries in other sectors (Costa \& Jongen, 2006). It is also considered relatively conservative when it comes to the introduction of the types of innovations to the market (Costa \& Jongen, 2006). However, with recent significant changes in the demand and supply of food, the growing level of domestic and international business competition have driven innovation to be a necessary business activity in the industry (Sarkar \& Costa, 2008). The need to respond to these changes have forced the food processing firms to adopt or practice innovative technological solutions and new business strategies for the mutual benefit of all firms (Bigliardi \& Galati, 2013). Nonetheless, food production is complicated as it involves a number of actors and the various, and inconsistent requirements of the intermediate customers, legislators and end-users (Mikkelsen, Kristensen, \& Nielsen, 2005; Costa \& Jongen, 2006). Furthermore, the actors in the food processing industry must enter into agreements with other individuals or firms to have new food technologies that are developed externally and to establish a close business relationship (Maula, Keil, \& Salmenkaita, 2006). This can improve the acceptance of those food technologies in the public and the success of the products in the business market (Costa \& Jongen, 2006).

The above considerations show that innovation in the food industry relies largely upon the activities and decisions of other actors involved in the innovation system. Therefore, firms in the food industry should open themselves to adopt open innovation strategies or models. This will help them to gain access to external knowledge, ideas, and skills in open innovation process. The existing literature shows that there are several models adopted by firms for open innovation in the food industry (Galanakis, 2016). Based on the purpose of this study, we will only describe the Sharing is Winning ( $\mathrm{SiW}$ ) and the Want, Find, Get, Manage (WFGM) models. Bigliardi and Galati (2013) indicated that these models could also be adopted by SMEs.

Sharing is Winning (SiW): This model was initially proposed by Traitler and Saguy (2009) in the food industry. According to Traitler, Watzke, \& Saguy (2011), the SiW model "extends the definition of OI, namely, a new avenue for collaboration in all areas of discovery and development with external partners who bring competence, commitment, and speed to the relationship, and also share the risk of innovation" (pp.63-64). This model consists of three levels of partnership for co-development: in universities, including research centers and institutes; in start-up firms and inventors; and through a particular number of important suppliers (Traitler \& Saguy, 2009). The aims of this model include: trust building, respect, and cooperative feelings with an emphasis on partners (Bigliardi \& Galati, 2013). The implementation of this model requires: selection of partner/s; co-creation of Intellectual Properties (IPs); a team to jointly and creatively solve the problems; best practices implementation; constant and maintainable activities affecting the people, culture, education, mindset, and metrics (Traitler \& Saguy, 2009). The implementation 
of the SiW model requires a paradigm shift. Thus, the leadership of the firms must not only accept or welcome the shift but also must take the risk of failure. The shift demands, for example, developing a clear vision, sustaining co-innovation, and cultural change (Traitler et al., 2011).

Want, Find, Get, Manage (WFGM): This model was introduced by Slowinski (2004). As the name indicates, it has four steps: Want, Find, Get, and Manage. The first step (WANT) refers to what knowledge a firm wants to achieve its growth objective/s. The second step is FIND, which refers to finding actors or partners who have the knowledge to fulfill the wants. The third stage is GET, which refers to acquiring of the knowledge or external sources through collaborative relationships. In the final step (MANAGE) the ongoing collaboration relationship must be managed by the firm to succeed (Slowinski \& Sagal, 2010). According to Garcia (2011), the WFGM is a widely adopted model by firms as a guide in their transition from closed to open innovation. In the implementation of the WFGM model, a cross functional team seeks, gains and manages the external non-physical assets, which in turn makes the open innovation process efficient (Bigliardi \& Galati, 2013). Furthermore, Garcia (2011) indicated that the extensive use of the WFGM model by firms could positively impact the success rate of new food products.

These models display that firms applying open innovation risk exposure of knowledge sharing. However, applying or using of these models are relevant in the context of open innovation by (food) SMEs if certain conditions are met, which include: improving their networking capability in order to overcome the challenges related to organizational and cultural issues, and/or to adopting different Intellectual Property (IP) strategies (see Table 2) or trust partners (see Section 4). Allen (2003) pointed out that firms use the IP or intellectual property rights (IPRs) not only to safeguard their competitive position in the market, but also to earn income from the innovations they create.

Table 2. Key characteristics of the SiW and WFGM models

\begin{tabular}{llll}
\hline Models & Benefits & Obstacles & IP protection \\
\hline SiW & - Major effectiveness and & - Further embraces open & -Confidentiality \\
& speeding up & culture & agreements \\
& of the innovation process & - Risk-taking activities & - Master joint agreements \\
& - Collaboration with & - Different value chain & for development \\
& highly motivated and & perceived by the & - Patenting \\
& skilled experts & food actors & \\
& - Minimization of risks & & \\
& for financial vows & & - Non-disclosure \\
\hline \multirow{2}{*}{ WFGM } & - Faster, better and more & - Difficulty in managing & agreements \\
& innovative capacity & the several & -Intensive arrangements \\
& - Increasing the number & relationships & for collaboration \\
& of collaborative & - Different focus of the & \\
& contracts & different involved actors &
\end{tabular}

Source: Adapted from Bigliardi \& Galati, 2013. 


\section{Methodology}

To answer the research question stipulated in Section 1, a qualitative research method was adopted, and a multiple case study approach was used. This approach not only decreases the probability of randomness, but also facilitates the researcher to "identify and study patterns across multiple cases" (Virlee et al., 2015, p. 113). To obtain rich data, multiple data sources were used such as a review of the available literature (journal papers and reports) and in-depth semi-structured interviews. Notably, with the help from UNIZO ${ }^{2}$ and web search, approximately 200 food SMEs were contacted to be interviewed. During the recruitment, the aim and criteria for the interview were explained. One of the main criteria in selecting an SME to be interviewed was that they were already engaged in the practice of open innovation. Consequently, only four food SMEs showed willingness to participate and thus four interviews (one interview per SME) were conducted in the Flanders region, Belgium. Four cases were sufficient, as usually in multiple case studies, no more than four or five cases are chosen by researchers (Creswell, 2012). Reasons that the remaining SMEs did not participate were various: such as the unwillingness to participate in research interviews, privacy concerns, busy schedules, or because they were not yet engaged in practicing open innovation. The interview questions were open-ended, which are listed in Appendix B.

As illustrated in Table 3 below, the staff headcount for each SME was less than 10. These SMEs were established in different years. All of the (four) respondents were males and on average they were almost 46 years old. Each SME had an annual turnover of less than 2 million Euros. The interviews were conducted in person in the office of each interviewee in English. The interviews were conducted by the first author ${ }^{3}$ between December 2017 and February 2018 with the senior staff of each SME, such as the CEO or Director, or founder. These participants were thought to be the most knowledgeable persons regarding the innovation strategy and practicing open innovation in their firms. The average duration of the interviews was approximately 96 minutes. Prior to the interviews, the participants were informed about the purpose of the research and consented to be interviewed and recorded on the iPhone $5 \mathrm{~S}$.

Once completed, the interview audio files were transcribed verbatim, and then thematically coded in NVivo software in order to be analyzed. For the purpose of trustworthiness (see Lincoln \& Guba, 1985), the interview data was shared with the interviewees before and after the analytical process. As suggested by Yin (2009), first within-case and then cross-case analysis was conducted. This enables the researchers to discern the similarities and differences in cases (Rothkopf, 2009). Since generalizability with a case study approach is challenging (Virlee et al., 2015), the generalization of the results beyond the cases under research in this study was avoided. However, suggestions are provided for further research on the subject beyond the Flanders region, Belgium (see Section 6).

\footnotetext{
2 It is "the largest organization for independent entrepreneurs, SMEs and the liberal professions" (for more details visit https://www.unizo.be/antwerpen).

3 The primary data was collected by the first author as part of his master thesis.
} 
Table 3. Brief overview of interviewees and SMEs

\begin{tabular}{clcc}
\hline SME & Interviewee position & Year of establishment & Staff headcount \\
\hline SME 1 & CEO & $1970 \mathrm{~s}$ & 7 \\
\hline SME 2 & Managing Director & 2015 & 7 \\
\hline SME 3 & CEO & 2012 & 9 \\
\hline SME 4 & Founder & $1920 \mathrm{~s}$ & 6 \\
\hline
\end{tabular}

\section{Case Studies}

This section describes the four cases from the interviews. The descriptions are based on inbound and outbound open innovation processes or activities, which are discussed in Section 2. Each case in this section mainly includes: (1) brief introduction; (2) the activities through which the SME has practiced open innovation; and (3) the views and experiences of the interviewees on IP protection and management.

\subsection{SME 1}

This firm is a family owned business that was founded in the 1970s. This firm has seven employees and produces spices, stocks, flavors, and fragrances to the market in and outside Belgium.

When interviewed, the CEO of this firm explained that the flavor sector is a bit new and it is facing challenges in terms of finding the right professionals. Therefore, this firm has been involved in practicing open innovation from the very beginning, but this practice was accelerated since 2014. The interviewee specified that "our customers are the main source of our internal product development." According to the interviewee, his firm works with the customers, suppliers distributors, and a flavor consultant. Customers do not actually produce the flavors, but they use the flavors. Thus, based on the ideas and information received from the customers, the external consultant integrates the ideas into the new product development process of SME 1. Additionally, the interviewee pointed out that they are using external innovative research labs and their collaboration with the FEVIA as a source of internal product and process development. This allows them to have certified water based on HACCP (Hazard Analysis and Critical Control Points) rules.

Through collaboration and networking with its customers, this firm is engaged and benefiting from practicing open innovation. The interviewee sees this as an important approach for his business and believes that ignoring the customers' ideas will strengthen his competitors in the market. He stated:

If we lock ourselves under the roof of our company then we will lose all the opportunities and possibilities, which are available outside of our firm. [...] through collaboration with our customers, we can learn a lot because customers have talent, knowledge, and most importantly expertise. 
In addition to its customers, the interviewee explained that they have collaborated and established networks with several private and public organizations. For example, they have established a networking relationship with the FEVIA, the Flanders' Chamber of Commerce and Industry (VOKA), and with the Belgian Flavor Association (AROMA) ${ }^{4}$. According to the interviewee, collaboration is a fast way of getting and sharing information. Moreover, it is essential to their business survival in the current competitive business environment. As a result of obtaining external ideas and knowledge and mixing them with the internal knowledge, this firm has innovated several products such as: Natural Chicken Flavor and Spray dried Chardonnay Wine Vinegar. These products are available with different flavors and tastes based on the demand of their customers. When asked about outbound open innovation activities (e.g., selling and revealing), the interviewee mentioned that they are not engaged in such kind of activities because they do not have sufficient resources (e.g., financial capital, technology, and human capital).

Regarding the IP protection and management, the interviewee described that it is difficult to secure and manage IP during collaboration with partners in the food industry, especially in the business of flavors which can be copied easily. Therefore, they have trust on their employees and partner/s that they will not copy their ideas and technology without their permission or agreement.

\subsection{SME 2}

This firm started operation in 2015 with the aim to produce fish in a sustainable way based on scientific research. Seven people are employed in this firm and it produces ecologically high and fast-growing fish species called Jade Perch (omega-perch) to the restaurants and supermarkets in Belgium and the Netherlands.

When asked about the practice of open innovation, the interviewee explained that they are engaged in practicing open innovation. He added that they get technical and professional knowledge from two public universities in Belgium and also from the Flanders Research Institute for Agriculture, Fisheries and Food (ILVO) for internal development and innovation. The interviewee said that "practicing open innovation has helped and optimized our infiltration processes, feeding the fishes, which are plant-based and also it has helped and improved our product quality."

In addition to collaborating with the universities and ILVO, this firm also collaborates with suppliers, supermarkets, clients, sometimes with SME 3, and even with some of its competitors. Interestingly, it has a win-win collaboration with one of its suppliers called Tomato Masters. This means that the water from this firm (SME 2), which is filtered, purified, and enriched, is used as a fertilizer for the cultivation of fresh tomatoes in the greenhouses of Tomato Masters. In return, the Tomato Masters supplies this firm (SME 2) with its surplus electricity to heat the water tanks to maintain the right temperature for the fish survival, especially during the winter season. According to the interviewee, they have outsourced their R\&D to PCG - a test center for vegetable growing, which is the leader in greenhouse crop and herb research.

\footnotetext{
4 AROMA is a member of the European Flavor Fragrance Association (EFFA). It has close communication with the European Food Safety Authority (EFSA), which is a member of the International Organization of the Flavor Industry (IOFI).
} 
Furthermore, this firm maintains networks with various public and private agencies. The interviewee stated that "networking with external bodies can save our time and money in obtaining external knowledge." He mentioned that their main networks linked to various institutions, including the Flanders Cleantech Association (FCA), the Traditional Food Network to Improve the Transfer of Knowledge for Innovation, and the ILVO. The interviewee explained that as a result of obtaining external knowledge, importantly, through collaboration, he has innovated, for instance, the water recirculation system and a formula to feed the fish only from plant-based materials.

Regarding the outbound open innovation activities, the interviewee mentioned that they have not yet engaged in these activities due to lack of necessary resources. However, they have a plan to do so in the future. When asked about the IP protection and management system, the interviewee mentioned that the IP protection is a valuable asset and his firm has its own trademark that nobody can copy or use without their agreement.

\subsection{SME 3}

This firm started operation in 2012. It has nine employees and mainly produces protein isolate, BSF lipids, and chitins with the help of larvae produced by black soldier fly (Hermetia illucens). The aim is to turn Belgium's waste into a resource in an environmentally friendly, sustainable and profitable manner.

When asked about the practice of open innovation, the interviewee explained that running this kind of business is impossible without practicing open innovation. He mentioned that they adopted open innovation at the time when they established this firm. According to the interviewee, there are three main reasons that they are engaged in practicing open innovation. First, for this business, they must develop three different technologies for breeding, rearing, and processing of insects, which requires an enormous amount of money that they never had. Therefore, they included several other firms, research institutions and universities from and outside Belgium. Second, this firm could not achieve these tasks alone. Third, the federal government in the Flanders supports firms if they work together for their internal development.

The interviewee pointed out that they are deeply motivated to practice open innovation and his firm is now one of the most successful firms in Belgium. To gain external knowledge and technology, this firm (SME 3) collaborates and networks with different organizations. For example, with the Agency for Innovation by Science and Technology (IWT), the VOKA, Flanders Innovation and Entrepreneurship (VLAIO), Belgian Insect Industry Federation (BIIF), and with the Food and Environment Research Agency (FERA) in the UK, and with the above-mentioned firm (SME 2). In addition, this firm has collaboration and networking with some universities in Flanders, the Wageningen University in the Netherlands, and the University of Parma in Italy. As a result of networking and collaboration, this firm has innovated larvae from black soldier fly and produces protein isolate, BSF lipids, and chitins.

Unlike the other SMEs in this study, SME 3 has out-licensed its technology. This is one of the sub-activities of outbound open innovation (see Section 2). The interviewee said that "we sold our technology to some international projects for the purpose of generating revenue and 
survival as a firm." Due to confidentiality issues, the interviewee avoided naming the projects or the firms. When asked about the process of out-licensing, the interviewee stated that "it's very complicated to explain." In addition, regarding the IP protection and management the interviewee stated:

In general, we must be careful about our firm's IP. Nonetheless, in the region of Flanders in Belgium, most of the firms rigorously follow their core business. So, they do not copy ideas or steal technological assets [...]. This culture has made open innovation possible in this region.

\subsection{SME 4}

This firm started operation in the early 1920s and has six employees now. Initially, it was producing only pasta, then later it expanded its food production to dehydrated soups (e.g., asparagus, carrot soup), broth sauces and stocks (e.g., chicken and fish). The aim of this firm is to support central kitchens, catering companies, food service, and food processing companies, particularly in Belgium.

On the topic of the practice of open innovation, the founder of SME 4 explained that his firm was involved in practicing open innovation right at the start of its business. For its internal development, this firm always listens to its customers, suppliers and distributors and then combines their ideas and knowledge with its own nearly one century in-house experience and knowledge.

In addition, the interviewee pointed out that due to lack of sophisticated technologies and high cost, they have outsourced the analysis of water and salt in their products to two private research laboratories. He mentioned that they have collaboration with different universities and government agencies in Belgium. For instance, they collaborate with Alimento. According to the interviewee, Alimento offers educational and professional classes for food firms to enhance their knowledge of the food industry. The cost of the classes is paid by the Flanders government. Furthermore, the interviewee mentioned that they have networks with a number of organizations, including Culinaria ${ }^{5}$, the FEVIA, the VOKA, University College Ghent, some schools, and the nursing homes.

As a result of networking and significantly through collaboration activities with different partners, SME 4 has innovated several products such as: (1) Silver Line Bouillons, a high - quality line of broths made up of beef, chicken and vegetables; and (2) new soup flavors. On the topic of the outbound open innovation activities, the interviewee mentioned that they are not engaged in outbound activities because they do not have sufficient resources. When asked about securing and management of the IP, the interviewee said that "it is difficult to protect our IP in the food and beverage industry, especially in small businesses, but we have confidence in our partners."

\footnotetext{
$5 \quad$ Culinaria is an association of producers and importers of soups, broths, and sauces.
} 


\section{Discussion}

\subsection{Inbound Open Innovation}

As explained in Section 2, inbound open innovation can be carried out by firms through two activities: acquiring and sourcing. More specifically, firms can acquire external knowledge or resources for its innovation process through formal networking, cooperation or collaboration, in-licensing, and outsourcing R\&D. In addition, external knowledge can be obtained through sourcing, which includes customer participation and informal networking activities (Virlee et al., 2015). The four SME cases in this study showed that they have obtained the external knowledge and ideas through both acquiring and sourcing activities. While fulfilling acquiring activities, it was found that collaboration, networking, and outsourcing were used by the SMEs in this study. Among them, collaboration with public and private firms and organizations is found to be a key activity to acquire external knowledge and ideas for internal development and innovating products. Interestingly, SME 2 had collaboration with some of its competitors and also had a win-win collaboration with one of its suppliers. This shows that this SME has the willingness to expand know-how through collaboration with its partners and a wellmanaged partner. Partner management in a reliable environment is an advantage for firms to form and improve relationships for win-win collaboration (Manceau, Moatti, Fabbri, Kaltenbach, \& Bagger-Hansen, 2011).

Despite the advantages of collaboration, Saguy \& Sirotinskaya (2014) indicated that collaboration "could lead to information leaks" (p. 141). However, in practice the SMEs in this study did not have any examples to show that information leakage occurred as a result of collaboration with their partners. This is mainly because they have trust in their partners and also some agreements (see Section 4). In addition to acquiring, sourcing was used to obtain ideas and knowledge. We found that two (SME 1 and SME 4) of the four SMEs in this study partly obtained knowledge from its customers for the purpose of product development. This is due to the nature of their business strategy, which is more customer oriented. This result is in line with the findings by Garavelli, Petruzzelli, Natalicchio, \& Vanhaverbeke (2013).

Overall, the findings from the practice of inbound open innovation activities show that the SMEs in this study are mostly involved in acquiring rather than sourcing activities. This is due to the fact that sourcing is an informal inbound activity to obtain ideas and knowledge. The task of acquiring is preferred by these food SMEs due to the complex nature of food production, which involves several actors and the various, and inconsistent requirements must be met by the food firms (see Section 2).

\subsection{Outbound Open Innovation}

Looking at outbound open innovation activities, within the four cases we found evidence that SME 3 is the only firm in our sample that has out-licensed its innovation or technology to generate revenue and maintain its business. However, the out-licensing process for SME 3 was complicated. Certainly, this type of activity necessitates significant management of resources and complex coordination (Bianchi, Campodall'Orto, Frattini \& Verseci, 2010). 
Synthesizing the inbound and outbound activities of open innovation, this study showed that food SMEs practice open innovation mostly through inbound open innovation activities rather than outbound. Previous studies also reached the same result, including food SMEs (e.g., Van de Vrande et al, 2009) and non-food SMEs, for instance, in the service sector (Parida et al, 2012; Virlee et al., 2015). This study found that the preference for inbound open innovation is largely a result of SMEs lacking sufficient resources (e.g., financial capital, technology, and human capital). This supports the findings of the previous studies that SMEs need more resources to practice outbound activities (e.g., Van de Vrande et al., 2009; Parida et al, 2012; Virlee et al., 2015). Notably, by looking at SME 1 and SME 4, it could be argued that food SMEs were engaged in practicing inbound open innovation a long time before the introduction of the concept of open innovation by the Chesbrough in 2003. This finding supports, for example, the study by Duarte and Sarkar (2011), who argued that the concept of open innovation is not entirely new.

The products developed or innovated by these four food SMEs as a result of inbound open innovation activities highlight the rapid innovation efforts of SMEs in the food industry. This finding can be in line with the findings reported by Fryer and Versteeg (2008). However, it contradicts the study by Hou and Mohnen (2013), who considered innovation efforts to be slow in the food industry and other traditional industries. Our findings also indicate that the food SMEs in the current study have knowledge of open innovation. Having knowledge of open innovation is among one of the indispensable factors contributing to the successful practice of open innovation by SMEs (Van de Vrande et al., 2009). However, there are SMEs that have little or no adequate knowledge about open innovation, which was one of the reasons that some of the food SMEs contacted about this research declined to participate.

As explained in section 2.3, the SiW and WFGM models can be relevant for the adoption of open innovation for SMEs. While this research has found some similarities between them, the $\mathrm{SiW}$ model has been more relevant within the scope of this study. In applying the models to the cases investigated in this study, it could be argued that the SiW model is more applicable in the context of practicing open innovation by the food SMEs. For example, the SMEs in this study were engaged in open innovation at the beginning of their business. Moreover, they have networking and collaboration with different partners (see Section 4). The $\mathrm{SiW}$ model is found as a crucial part of open innovation and it can enhance collaboration among partners (Saguy \& Sirotinskaya, 2014). Moreover, SiW is identified as a sustainable model for firms because "the risk of making financial commitments too early in the project(s) is kept low" (Traitler et al, 2011, p. 64). The WFGM model is used more as a guide when SMEs are in transition from closed to open innovation (see Section 2). Bigliardi and Galati (2013) viewed that the WFGM model is the most used when adopting open innovation by food SMEs or firms. However, they pointed out that its implementation is difficult, for instance, when compared to the SiW model. This is because the WFGM model requires a firm to change its whole organizational structure, including the organizational culture (Bigliardi \& Galati, 2013).

\section{Conclusions and Recommendations}

The purpose of this paper was to examine how food SMEs practice open innovation with a focus in 
the Flanders region, Belgium. We found that SMEs in the food industry practice open innovation mostly through inbound open innovation activities rather than outbound. This is largely because food SMEs typically lack financial capital, technology, and human capital - a problem which likely does not exist in large firms. Within inbound open innovation activities, collaboration with organizations was found to be a key element for food SMEs' internal development and innovation of new products compared to networking, in-licensing, and outsourcing R\&D. The practice of open innovation, mainly through collaboration by some SMEs, shows that open innovation is not an entirely new concept developed by Henry Chesbrough in 2003.

Based on the findings and discussions in this study, we provide the following recommendations, which will be beneficial for SMEs or firms in the food industry.

- Practicing open innovation is important for food SMEs to survive in the current competitive business environment. Therefore, SMEs that practice open innovation should maintain and expand their networks and collaboration with trustworthy agencies and partners. SMEs that have not yet practiced open innovation should start. Otherwise, they will miss out on benefitting from the wide range of external resources and technologies available. For collaboration, SMEs should have agreements with their partners and/or proper IP protection and management system to avoid pitfalls and unnecessary misunderstandings during the implementation process.

- Managers or the CEOs of SMEs should approach collaboration with open minds with food firms who have a different culture than their own. This can be an important initiative in encouraging successful collaborative efforts, which can lead SMEs to internal development and profitability.

- The food industry plays a vital role in the economic development of many countries (e.g., see McKay, 2007; Food \& Drink Europe, 2018). Therefore, the Belgian government should expand their support towards tackling the financial, human capital and technological related barriers for food SMEs. This is possible through different approaches, such as providing grants or loans, needs-based free training, and enhancing support in collaborative work among the interested SMEs. Among others, the practice of these actions will help to encourage SMEs managers to accelerate, improve and enhance their innovation processes.

- The government in coordination with the (federation of) food industry should pay special attention in supporting food enterprises to participate in international food exhibitions in different countries. This will help food SMEs to be further aware of the current food trends, challenges and innovations in the industry. Additionally, it can be beneficial for SMEs to find new partners for collaborations, networks, and attracting new customers.

\subsection{Limitations and Further Research}

This study can contribute to the literature on the practice of open innovation by SMEs in the food industry with a focus in the Flanders region, Belgium. However, some limitations and recommendations for further research can be acknowledged. First, the findings in this study cannot be generalizable as it has only used four cases from the SMEs in the food sector, while many other SMEs refused to participate (see Section 3). Therefore, there is a need for further 
research to broaden the amount of cases with the focus in more than one region in Belgium as well as beyond Belgium to achieve results that can be more widely applicable. Second, due to limited time, this study only focused on the food industry, but further research should be conducted to compare how open innovation is practiced outside of the food industry such as hospitality, sport and services industries. Third, as a qualitative research method is used in this study, the analysis can be subjective; therefore, a quantitative research or mixed methods is suggested for the future research to increase the precision of the study. Fourth, since the focus on IP protection and management of SMEs was beyond the scope of this study, it may be interesting for future studies to focus in detail on how SMEs can secure and manage IP while practicing open innovation. Fifth, this study found that trust between partners is an important factor for SMEs in practicing open innovation. Thus, further studies should be conducted on the relationship between interpersonal trust and trust between firms in the context of open innovation. Sixth, a specific study should be conducted on the motivations and challenges related to the practice of open innovation by food SMEs and on the role of government funds in encouraging the practice of open innovation in SMEs in the food industry.

\section{References}

Allen, K. R. (2003). Bringing new technology to market. Pearson College Division.

Barney, J. (1991). Firm resources and sustained competitive advantage. Journal of management, 17(1), 99-120.

Barney, J. B., Ketchen Jr, D. J., \& Wright, M. (2011). The future of resource-based theory: revitalization or decline?. Journal of management, 37(5), 1299-1315.

Bigliardi, B., \& Galati, F. (2013). Models of adoption or open innovation within the food industry. Trends in Food Science 83 Technology, 30 (1), 16-26.

Bianchi, M., Campodall'Orto, S., Frattini, F., \& Vercesi, P. (2010). Enabling open innovation in small and medium-sized enterprises: How to find alternative applications for your technologies. RESD Management, 40(4), 414-431.

Bapuji, H., Loree, D., \&Crossan, M. (2011). Connecting external knowledge usage and firm performance: An empirical analysis. Journal of Engineering and Technology Management, 28(4), 215-231.

Bogers, M., Zobel, A. K., Afuah, A., Almirall, E., Brunswicker, S., Dahlander, L., ...\& Hagedoorn, J. (2017). The open innovation research landscape: Established perspectives and emerging themes across different levels of analysis. Industry and Innovation, 24(1), 8-40.

Chesbrough, H., \& Crowther, A. K. (2006). Beyond high tech: early adopters of open innovation in other industries. REd Management, 36(3), 229-236.

Costa, A. I., \& Jongen, W. M. F. (2006). New insights into consumer-led food product development. Trends in Food Science 83 Technology, 17(8), 457-465. 
Creswell, J. W. (2012). Qualitative inquiry and research design: Choosing among five approaches (3rd ed). Thousand Oaks, CA: Sage.

Chesbrough, H., \& Bogers, M. (2014). Explicating open innovation: Clarifying an emerging paradigm for understanding innovation. New Frontiers in Open Innovation. Oxford: Oxford University Press, Forthcoming, 3-28.

Chesbrough, H. W. (2003). Open Innovation: the new imperative for creating and profiting from technology. Harvard Business School Publishing Corporation.

Chesbrough, H., Vanhaverbeke, W., \& West, J. (Eds.). (2006). Open innovation: Researching a new paradigm. Oxford University Press on Demand.

Daft, R. (1983). Organization theory and design. New York: West.

Duarte, V., \& Sarkar, S. (2011). Separating the wheat from the chaff - a taxonomy of open innovation. European Journal of Innovation Management, 14 (4), 435-459.

de Best. (2019, February 20). Total number of small and medium enterprises (SMEs) in Flanders, Wallonia and the Brussels Capital Region (Belgium) from 2007 to 2017. Statista. Retrieved April 03, 2019, from Statista website: https://www.statista.com/statistics/818783/ number-of-smes-in-belgium-by-region/

Dahlander, L., \& Gann, D. M. (2010). How open is innovation? Research policy, 39(6), 699709.

Durst, S. and Ståhle, P. (2013). "Success factors of open innovation - a literature review", International Journal of Business Research and Management (IJBRM), 4(4), 111-131.

FEVIA. (2017-2018). Economic development of the Belgian Food industry [Economische ontwikkeling van de Belgische Voedingsindustrie]. Febia, Belgium. Retrieved April 03, 2019 from Fevia website, https://www.fevia.be/sites/fevia/files/media/documenten/fevia_economisch_jaarverslag_ 2017_nl.pdf

Fryer, PJ, \& Versteeg, C. (2008). Processing technology innovation in the food industry. Innovation, 10 (1), 74-90.

Food \& Drink Europe. (2018). Data \& Trends EU Food and Drink Industry 2018. Brussels: Food Drink Europe.

Gassmann, O. (2006). Opening up the innovation process: towards an agenda. REd Management, 36(3), 223-228.

Gassmann, O., Enkel, E., \& Chesbrough, H. (2010). The future of open innovation. RED Management, 40(3), 213-221.

Garavelli, C. A., Petruzzelli, M. A., Natalicchio, A., \& Vanhaverbeke, W. (2013). Benefiting from markets for ideas-An investigation across different typologies. International Journal of Innovation Management, 17(6).

Garcia, M. (2011). Future R\&D strategies in food and drinks: evolution from orthodox approach to open innovation. In IFAMA Annual World Symposium, 20e21 June 2011 Frankfurt, Germany. 
Galanakis, C. M. (Ed.). (2016). Innovation strategies in the food industry: Tools for implementation. Academic Press.

Hutter, K., Hautz, J., Repke, K., \& Matzler, K. (2013). Open innovation in small and micro enterprises. Problems and Perspectives in Management, 11(1), 12-22.

Huizingh, E. (2011). Open innovation: State of the art and future perspectives. Technovation, 31(1): 2-9.

Hou, J., \& Mohnen, P. (2013). Complementarity between in-house R\&D and technology purchasing: evidence from Chinese manufacturing firms. Oxford Development Studies, 41(3), 343371.

Lichtenthaler, U., \& Ernst, H. (2007). External technology commercialization in large firms: results of a quantitative benchmarking study. RED Management, 37 (5), 383-397.

Lee, S., Park, G., Yoon, B., \& Park, J. (2010). Open innovation in SMEs-An intermediated network model. Research policy, 39(2), 290-300.

Lee, K., \& Yoo, J. (2019). How does open innovation lead competitive advantage? A dynamic capability view perspective. PloS one, 14 (11).

Lincoln, Y., \& Guba, E. G. (1985). Naturalistic inquiry. Newbury Park, CA: Sage

Maula, M., Keil, T., \&Salmenkaita, J.-P. (2006). Open innovation in systemic innovation contexts. In H. W. Chesbrough, W. Vanhaverbeke, \& J. West (Eds.), Open innovation: Researching a new paradigm (pp. 241e257). Oxford: Oxford University Press.

Manceau, D., Moatti, V., Fabbri, J., Kaltenbach, P. F., \& Bagger-Hansen, L. (2011). Open innovation-What is behind the buzzword. ESCP Europe and Accenture.

Mikkelsen, B. E., Kristensen, N. H., \& Nielsen, T. (2005). Innovation Processes in LargeScale Public Foodservice - Case Findings from the Implementation of Organic Foods in a Danish County. Journal of Foodservice Business Research, 8(2), 87-105.

Muller, A., Hutchins, N., \& Pinto, M. C. (2012). Applying open innovation where your company needs it most. Strategy \& Leadership, 40(2), 35-42.

McKay, J. (2007). Food industry \& economic development in the Asia Pacific. Asia Pacific journal of clinical nutrition, $16(\mathrm{~S} 1), 80-84$.

OECD. (2015). Entrepreneurship at a Glance 2015. OECD, Paris. Retrieved April 07, 2019, from OECD-iLibrary website: https://www.oecd-ilibrary.org/docserver/entrepreneur_aag-2015en.pdf? expires $=1563790292 \& \mathrm{id}=\mathrm{id} \&$ accname $=$ ocid195767\&checksum $=2 \mathrm{D} 5 \mathrm{DA} 5 \mathrm{~A} 384 \mathrm{~EB} 03 \mathrm{CC} 261 \mathrm{E} 4 \mathrm{FD} 43893 \mathrm{~A}$

OECD. (2016). "Belgium", in Financing SMEs and Entrepreneurs 2016: An OECD Scoreboard, OECD Publishing, Paris.

OECD. (2017). Enhancing the Contributions of SMEs in a Global and Digitalized Economy. OECD, Paris. Retrieved April 07, 2019, from OECD, website: https://www.oecd.org/mcm/ documents/C-MIN-2017-8-EN.pdf

Parida, V., Westerberg, M., \& Frishammar, J. (2012). Inbound open innovation activities in 
high-tech SMEs: the impact on innovation performance. Journal of small business management, 50 (2), 283-309

Ray, G., Barney, J. B., \& Muhanna, W. A. (2004). Capabilities, business processes, and competitive advantage: choosing the dependent variable in empirical tests of the resource-based view. Strategic management journal, 25(1), 23-37.

Rahman, H., \& Ramos, I. (2010). Open Innovation in SMEs: From closed boundaries to networked paradigm. Issues in Informing Science and Information Technology, 7(4), 471-487.

Rothkopf, M. (2009). Innovation in Commoditized Service Industries: An Empirical Case Study Analysis in the Passenger Airline Industry (2). Münster: LIT Verlag.

Sarkar, S., \& Costa, AI (2008). Dynamics of open innovation in the food industry. Trends in Food Science \& Technology, 19(11), 574-580.

Slowinski, G. (2004). Reinventing corporate growth. Gladstone. NJ: Alliance Management Press.

Slowinski, G., \& Sagal, M. W. (2010). Good practices in open innovation. Research Technology Management, $38 \mathrm{e} 45$.

Saguy, IS, \& Sirotinskaya, V. (2016). Open innovation opportunities focusing on food SMEs. In Innovation Strategies in the Food Industry (pp. 41-59). Academic Press.

Saguy \& Sirotinskaya, V. (2014). Challenges in exploiting open innovation's full potential in the food industry with a focus on small and medium enterprises (SMEs). Trends in Food Science 8 Technology, 38 (2), 136-148.

Trott, P., \& Hartmann, D. A. P. (2009). Why 'open innovation' is old wine in new bottles. International Journal of Innovation Management, 13(04), 715-736.

Traitler, H., \& Saguy, IS (2009). Creating successful innovation partnerships. Food technology.

Traitler, H., Watzke, HJ, \& Saguy, IS (2011). Reinventing R\&D in an open innovation ecosystem. Journal of food science, 76 (2), R62-R68.

Usman, M., Roijakkers, N., Vanhaverbeke, W., \& Frattini, F. (2018). A systematic review of the literature on open innovation in SMEs. In Researching Open Innovation in SMEs, 1-28.

Van de Vrande, V., De Jong, J. P., Vanhaverbeke, W., \& De Rochemont, M. (2009). Open innovation in SMEs: Trends, motives and management challenges. Technovation, 29(6-7), 423437.

Virlee, J., Hammedi, W., \& Parida, V. (2015). Open innovation implementation in the service industry: exploring practices, sub-practices and contextual. Journal of Innovation Management, 3(2), 106-130.

Yin, R. K. (2009). Case study research: Design and methods (4th ed.). Thousand Oaks, CA: Sage Publications. 


\section{Appendixes}

\section{Appendix A:}

Table A.1. Open innovation versus closed innovation principles

\begin{tabular}{ll}
\hline Open innovation & Closed innovation \\
\hline "Not all of the smart people work for us, so we & "Most of the smart people in our field \\
must find and tap into the knowledge and & work for us" \\
expertise of bright individuals outside our & \\
company" & \\
\hline "External R\&D can create significant value; & "To profit from R\&D, we must discover, \\
internal R\&D is needed to claim some portion of & develop and ship it ourselves" \\
that value" & \\
\hline "We don't have to originate the research in order & "If we discover it ourselves, we will get it \\
to profit from it" & to market first" \\
\hline "Building a better business model is better than & "If we are the first to commercialize an \\
getting to market first" & innovation, we will win" \\
\hline "If we make the best use of internal and external & "If we create the most and best ideas in \\
ideas, we will win" & the industry, we will win" \\
\hline "We should profit from others' use of our IP, and & "We should control our intellectual \\
we should buy others' IP whenever it advances & $\begin{array}{l}\text { property (IP) so that our competitors } \\
\text { our own business model" }\end{array}$ \\
\hline
\end{tabular}

Source: Retrieved from Chesbrough (2003, p. xxvi)

\section{Appendix B:}

Interview questions ${ }^{6}$

\section{Introductory questions}

\section{Open innovation practice}

What is your main motivation for adopting or practicing Open Innovation in your business?

When did you move from Closed to Open Innovation? How? When? Why?

Did the practice of Open Innovation create any competitive edge to your business?

Do you have collaboration partnerships with external parties such as market based sources (e.g., suppliers, distributors, customers, competitors, firms from other industries, etc.), science based sources (e.g., universities, technical colleges, research etc.), government agencies, SMEs and start-ups and designers? If yes, with whom? Which entity? Why? Please elaborate.

\footnotetext{
6 Several questions were elaborated for the interviewees during the interviews and follow up questions were asked.
} 
How do you select these organizations or partners for collaboration? Are there any specific criteria for partner's selection that you want to mention?

What are the main advantages and disadvantages of collaboration? Did collaboration help your business?

Which kind of knowledge, idea, technology and information do you get and share with these external partners?

How do you maintain your collaboration with the organizations or partners?

How are you managing intellectual property (IP) protection mechanisms (patents, copyrights, trademarks and secrets, NDA) while collaborating with external partners?

Do you have any networking relationship with government and private agencies? Which agencies and How?

Have you ever utilized or acquired outside/external resources, ideas, knowledge and technologies through in-licensing, formal networking, cooperation or collaboration and outsourcing R\&D? Please elaborate.

How did the external knowledge sources help your SME in terms of innovation?

How often do you get feedback from your customers/consumers, suppliers, intellectual property rights experts, universities, laboratories and network partners in the evaluation and testing of new products and development?

Have you ever been forced by the feedback of the customers to interact with external environment in order to meet their demand?

Have you ever commercialized your innovation, resources, knowledge and technology through selling or out-licensing it to the external environment? If yes, how? If no, why?

Do you have any suggestions or would you like to add any information, which is important but I have not asked you. 


\section{Biographies}
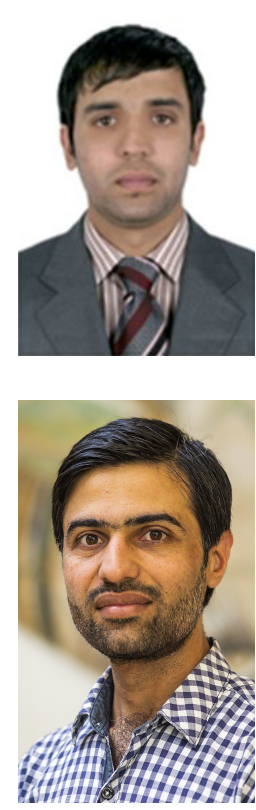

editing (lead).
S. Hijrat Sadat. S. Hijrat Sadat received MSc in Management with specialization in International Marketing Strategy from the Faculty of Business Economics, University of Hasselt, Belgium, in 2018. Presently, he is a Product Development Analyst and Project Coordinator with a multinational company in Belgium. In addition, he has several years of professional work experience with different government institutions, national and international organizations, and NGOs in the field of project management, consulting, coordination, change management, and capacity building. His research interests include open innovation in SMEs, collaborative ideations, rural and economic development, project management, and change management.

CRediT Statement: Conceptualization (lead); methodology (lead); Investigation (lead)

Sayed Nasrat. Sayed Nasrat received MSc in Public Policy and Human Development from Maastricht University/United Nations University-MERIT, the Netherlands, in 2018 and MS in International Cooperation Policy from Ritsumeikan Asia Pacific University (APU), Japan, in 2014. Presently, he is a researcher with the Maastricht Graduate School of Governance (MGSoG)/United Nations University-MERIT, Maastricht University. He was a former researcher with the Ministry of Rural Rehabilitation and Development (MRRD) in Afghanistan, and Integrity Watch Afghanistan. His research interests include development economics, foreign aid, rural development, anti-corruption, refugee integration, diaspora mapping and engagement, social protection, and open innovation. This article is not part of the author's affiliated institutions.

CRediT Statement: Formal analysis (lead); writing original draft (lead); writing - review and 